\title{
Integrating Field and GIS-based Surveys to Map the Distribution and Characterize the Ecological Habitat for Conservation Management of Georgia Plume, a Rare Endemic
}

\author{
Justin A. Porter, David Berle, and Hazel Y. Wetzstein ${ }^{1}$ \\ Department of Horticulture, 1111 Miller Plant Science Building, The University \\ of Georgia, Athens, GA 30602
}

Additional index words. habitat survey, plant conservation, Elliottia racemosa

\begin{abstract}
Accurate mapping, inventory assessment, and habitat descriptions are critically important for the development of plant conservation strategies of rare plants. Georgia plume, Elliottia racemosa (Ericaceae), is a rare threatened plant endemic only to the state of Georgia. In this study, census and distribution data were collected and the ecological habitat characterized for all known populations of georgia plume using geographic information system/global positioning system (GIS/GPS)-based methods. Causes for population losses and decline were assessed by evaluating both extant populations and historically reported but currently inactive sites. Landowner permission was obtained to visit 56\% (32 of 57) of all known recorded populations. Over $40 \%$ of visited locations no longer contained georgia plume; $58 \%$ of inactive sites were associated with anthropogenic disturbances including farming and timber. Populations not visited by ground were evaluated using aerial photographs: of 29 putative populations, $66 \%$ were judged highly unlikely to contain georgia plume based on current land use. Census data verified that many populations have few individuals: $75 \%$ contained less than 45 individuals; over one-third contained 12 or fewer individuals. Over $80 \%$ of extant populations had an area of less than 0.3 ha. Field and aerial assessments of recent and historically noted populations confirm that georgia plume has disappeared from many previously reported locations and that fewer than two dozen populations may remain.
\end{abstract}

Understanding the current status of rare plant populations is critical for the development of conservation strategies. Critical types of needed information include updated inventories, accurate mapping and knowledge of population dynamics, ecological characterization of habitats, and an understanding of the effects of anthropogenic disturbances. Unfortunately, such information is often lacking for many rare plants species. Several different types of conservation projects have begun adopting the use of geographic approaches (Alexander et al., 2005; Anderson and MartinezMeyer, 2004; Vanderpoorten et al., 2005). GIS/GPS methods can be effectively used in data collection, record management, and population inventorying. GIS further allows analysis to be conducted across several different layers of environmental variables (Clark et al., 1993). This enables models to be developed

Received for publication 15 Oct. 2012. Accepted for publication 2 Jan. 2013.

We thank Lisa Kruse and the Georgia Department of Natural Resources for providing assistance in identifying known georgia plume populations, Lara Jackson for assistance with field work, and Henry Mincy for identifying populations within Fort Stewart Military Reservation.

${ }^{1}$ To whom reprint requests should be addressed; e-mail hywetz@uga.edu. that characterize current habitats and predict unknown habitat locations (Rotenberry et al., 2006). Knowledge concerning the exact locations and environmental requirements of threatened and endangered plants is crucial when developing management plans. With this information, managers can make informed decisions regarding establishment of protected areas, collection for ex situ conservation, and exploration for unknown populations.

Georgia plume [Elliottia racemosa (Ericaceae)] is a small tree that is endemic only to the state of Georgia, where it is listed as a threatened species (Georgia Department of Natural Resources, 2006). Georgia plume is known for its large, white, plume-like inflorescences that are born in June and July. First discovered by William Bartram in the 1770 s (Ewan, 1968), it is confined mainly to the Coastal Plain region. Georgia plume is one of the rarest native plants in Georgia (Santamour, 1967). Attesting to the rarity of the species, no wild populations were known from $\approx 1875$ to 1901, during which time georgia plume was thought to be extinct in the wild. More recent assessments have described the plant to occur in $\approx 36$ locations (Patrick et al., 1995). However, many reported populations are now thought to be destroyed or much reduced (Chafin, 2007).

The extreme scarcity of the plant is caused in part by low to no fruit production that has been observed for much of the plant's known history and noted by several authors (Del Tredici, 1987; Elliott, 1821; Faircloth, 1970; Fordham, 1991; Miller, 1978). In recent times, no seedling recruitment has been observed in the wild. Our recent work suggests georgia plume may have reproductive challenges, including low pollen viability, separation in the timing of male and female function within flowers, and sexual self-incompatibility (Radcliffe et al., 2010). Low genetic diversity has been reported from allozyme analysis of several populations (Godt and Hamrick, 1999). In a molecular analysis of georgia plume populations using random amplified polymorphic DNA, the small number of individuals and geographic isolation characteristics of many populations were associated with high within-population genetic similarity suggesting that narrow genetic variation in some populations may be contributing to lack of sexual reproduction in the wild (Porter et al., 2012). The combination of these factors explains serious biological reasons for the rarity of the species in the wild.

In addition to reproductive issues, habitat loss is likely a contributing factor to losses of georgia plume. The clearing of forest lands for agricultural and timber uses is a major contributor to georgia plume habitat loss (Duncan and Duncan, 1978; Patrick et al., 1995). Modern land use techniques including increased agricultural land use have been shown to pose threats to sensitive plants. Anthropogenic influences can be major contributors to loss of diversity, habitat, and populations of rare plants (Brockerhoff et al., 2008; Ceballos et al., 2010; Vargas-Rodriguez and Platt, 2012).

Georgia plume has been reported to appear in a range of habitats including sand ridges, dry oak ridges, evergreen hammocks, sandstone outcrops, and sandy soil conditions ranging from moist to xeric (Patrick et al., 1995). The apparently wide variety of habitats but limited number of locations in which georgia plume occurs has made it difficult to draw any definitive conclusions as to the distribution and preferred habitat of the species. Current distribution maps are often based on plant sightings and contain limited environmental data. In the current study, GPS- and GIS-based surveys were integrated to map the distribution and characterize the ecological habitat of georgia plume. An advantage of this approach is that locations of populations and individual trees can be accurately recorded, which can be extremely useful in long-lived species. This is paramount when locating georgia plume populations because they tend to be small in size. It is also possible to conduct censuses of populations and determine distances between individuals for use in other studies such as genetic analysis. Other advantages of keeping population records in a GIS are the ability to store several types of attributes easily, flexibility in recording information as needed, and ease in updating attribute information. By recording habitat attributes concurrently with spatial information, analyses of populations or individuals 
can be conducted on these attributes in relation to other environmental variables. This would lead to a better understanding of the diverse environmental conditions in which georgia plume occurs.

In this study, census and distribution data were collected, and the ecological habitat was characterized for all known populations of georgia plume. The objectives of this study were to: 1) develop a GIS-based conservation management tool capable of inventorying populations and recording habitat conditions; and 2) assess potential causes for population losses and decline by relating previously described historic locations containing georgia plume with currently active and inactive sites. Spatial and environmental data were collected during field visits. In cases in which ground visits were not possible, aerial analysis was used. Although information presented here is specifically related to georgia plume, the methodology could readily be used as a model system for other threatened or endangered species.

\section{Materials and Methods}

Study area. Elliottia racemosa, georgia plume, is endemic only to the state of Georgia, with all known populations occurring within the state. The study area included all of the known distribution, which is contained within 16 counties (Fig. 1): Ben Hill, Bryan, Bulloch, Burke, Candler, Coffee, Columbia, Emanuel, Evans, Irwin, Jeff Davis, Long, Tattnall, Telfair, Turner, and Wheeler. The entirety of this area is located

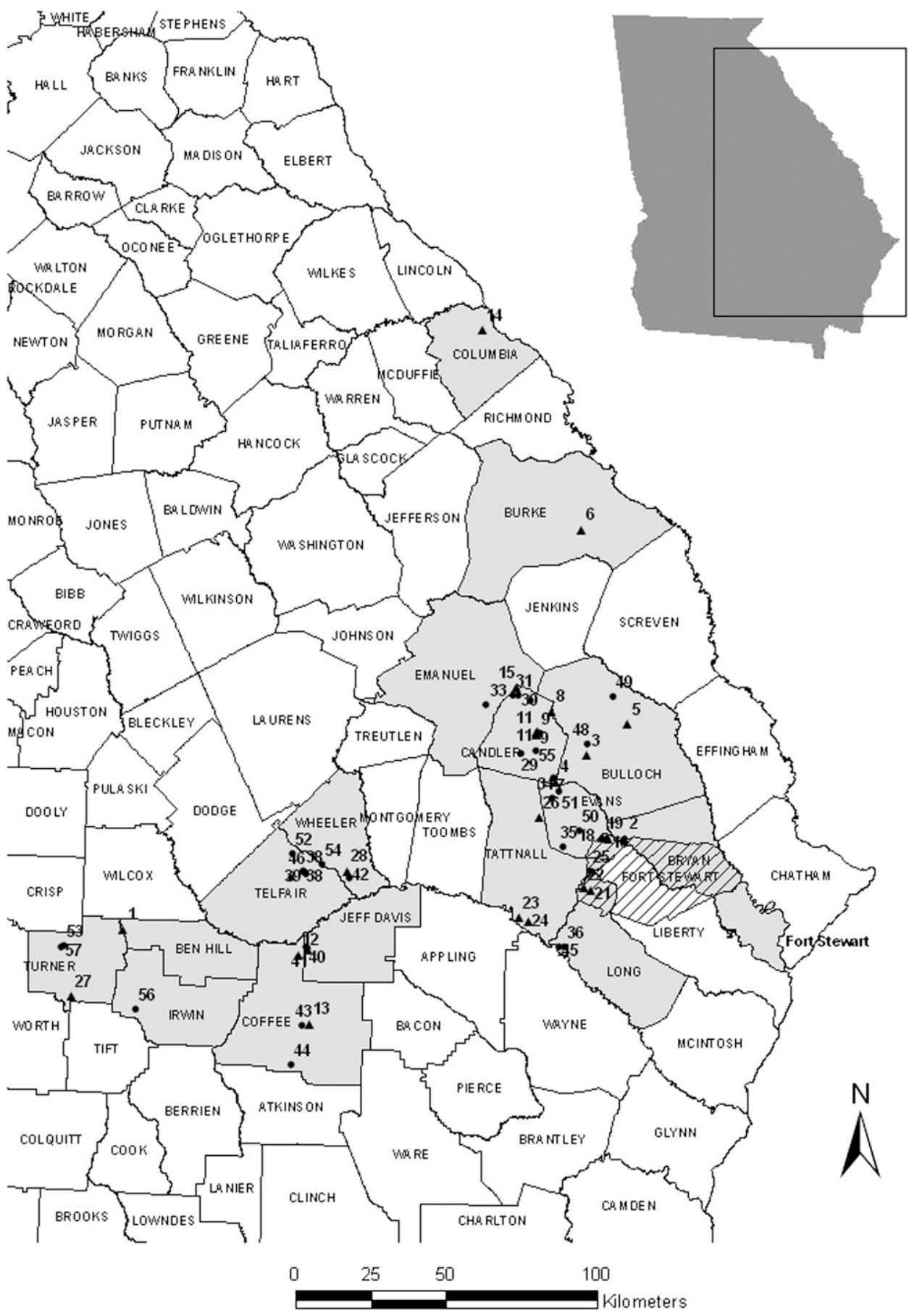

Fig. 1. Mapped area within the state of Georgia showing counties and locations of putative georgia plume populations identified from Department of Natural Resources databases. Counties reported to contain georgia plume are in gray. Triangles are sites that were visited by ground with census/habitat data collected. Dots are putative populations that were not visited as a result of lack of landowner permission and evaluated instead using aerial photography. Numbers identify populations referred to later in the article. Areas marked with diagonal lines are Fort Stewart Military Reservation property. 
between lat. $33^{\circ} 42^{\prime} 27^{\prime \prime} \mathrm{N}$ and lat. $31^{\circ} 22^{\prime} 27^{\prime \prime} \mathrm{N}$ and between long. $81^{\circ} 8^{\prime} 13^{\prime \prime} \mathrm{W}$ and long. $83^{\circ} 47^{\prime} 20^{\prime \prime} \mathrm{W}$. Populations are confined mainly to the Coastal Plain of eastern Georgia; however, one population is located in the lower Piedmont region.

Putative site locations for georgia plume populations were obtained in shapefile format from the Georgia Department of Natural Resources. These 57 locations ranged from recently verified populations to historical annotations dating to the 1970 s and represent all the known recorded populations for georgia plume. Using these points as a reference, requests were sent to landowners for permission to visit and document conditions at as many sites as possible. Permission was obtained to visit 32 populations $(56 \%$ of all known populations). Individual populations are referred to by assigned number. Populations not visited by ground were evaluated using aerial photographs.

Population and habitat data collection. A data collection form was developed for use in ArcPad 7.1.1 (ESRI; Environmental Systems Research Institute, Inc., Redlands, CA) to record information at sites that were visited. Ground data assessment variables included whether georgia plume plants were still present at the site, plant characteristics, ground conditions, canopy conditions, and land use. Data were recorded at the approximate center of sites that had homogenous conditions throughout the population. At larger sites where habitat characteristics changed within the population, data were recorded in the disparate areas to capture the changes.

At each of the visited populations, a census of georgia plume plants was taken with the total number of individuals present within a population noted. At sites where georgia plume was present, the location of individual georgia plume plants was recorded using GPS coordinates except in populations containing more than 100 individuals. Georgia plume plant characteristics were recorded, i.e., general plant form (sucker, shrub, or tree), position in the canopy (understory or overstory), and evidence of reproduction (flower or fruiting structures). The perimeter of each population was mapped to provide information on the geographical size and configuration of populations.

Several pieces of environmental data were collected at the visited sites. The general habitat was categorized into types, which included flatwoods, sandhills, oak hammock, mesic, palmetto woods, sandstone outcrops, slopes, mixed bottom lands, and transitions between slope and bottom land. Canopy characteristics of the site such as type (deciduous, evergreen, or mixed) and closure (open, partially closed, or greater than $75 \%$ closed) were recorded. The type of soil cover (ground plants, leaf and needle litter, or a mixture of the two) was recorded along with the duff (litter layer) thickness on the soil surface. Evidence of burning exemplified by the presence of charred bark on trees or burned ground plants was noted. Habitat conditions at all visited sites were recorded including both active sites containing georgia plume and those that no longer contained georgia plume plants.

Sites that could not be assessed by a field visit as a result of lack of landowner permission were examined using aerial photographs in ArcGIS Explorer (ESRI). Based on canopy cover and apparent site conditions, aerial photographs were used to ascertain whether the site potentially contained georgia plume plants. Land use activities at a site which included pine plantations or clear-cuts, agricultural fields, cleared land, and indicators of urbanization such as buildings were used as estimators for the absence of georgia plume plants. Sites composed of mixed hardwoods or deciduous/evergreen canopies were designated as needing ground visitation for confirmation.

\section{Results and Discussion}

Identification, census, and characterization of populations. Fifty-seven putative georgia plume populations were identified from records of recent and historic sightings provided by the Georgia Department of Natural Resources (Fig. 1). It should be noted that populations may or may not have been visited recently. The listing of putative populations was gathered from databases with notations that ranged from recent description to those made in the 1970 s. All previously recorded populations were included in this study regardless of the last time the population was visited. To obtain current landowner addresses, records from respective county tax assessors' offices were used, and several attempts were made to contact landowners. Permission was obtained to visit $56 \%$ of all historically sighted populations on record, i.e., 32 of the 57 sites. No response was obtained for the remaining inquiries despite multiple attempts to contact landowners. Of the sites for which permission was granted, ground visits were made to 28 locations; four sites were found to be inaccessible, i.e., within fenced off areas, distant/unapproachable by roads, etc.
Figure 1 shows the locations of the compiled putative georgia plume populations, designating both those that were field-visited as well as the sites that were not accessed by ground.

Of the visited sites, only $57 \%$ ( 16 of 28 ) of the putative populations still contained georgia plume plants and are designated in this article as "active sites." A substantial number of locations, $43 \%$ of the visited sites (12 of 28 locations), were found to no longer contain georgia plume plants (designated as "inactive"). These assessments confirm that many georgia plume populations have disappeared and substantiate that a precipitous decline in population numbers has occurred within the last several decades.

Census information and population geographical area parameters of extant, active populations are summarized in Table 1 . Many of the georgia plume populations were composed of few individuals. Seventy-five percent of the populations contained less than 45 individual plants. Over one-third of the populations (six of 16 populations) contained merely a dozen or fewer individuals. Only three of the 16 active populations visited had plant numbers of over 100 . Two populations (No. 24 and No. 9) are under protection by the Georgia Department of Natural Resources and Nature Conservancy, respectively, and are among the four largest populations. The census data shown in Table 1 clearly verify the extremely low numbers of georgia plume plants that exist in the wild. Some populations have critically low numbers of trees; three populations have less than 10 individuals. Species occurring in small or isolated populations can face a higher risk of extinction. In a study evaluating population size and survival of several threatened plants, Matthies et al. (2004) found negative effects of small population size on survival. Coates et al. (2007) examined several different plant populations and found that as numbers of individuals within a mating population decreased, the potential for inbreeding greatly increased. Inbreeding, loss of genetic variation, and the accumulation of deleterious

Table 1. Census information, population geographical parameters, and characteristics of georgia plume plants at extant populations verified by field visits.

\begin{tabular}{llccclcc}
\hline $\begin{array}{l}\text { Population } \\
\text { no. }\end{array}$ & County & $\begin{array}{c}\text { No. of } \\
\text { georgia } \\
\text { plume plants }\end{array}$ & $\begin{array}{c}\text { Area } \\
\text { (ha) }\end{array}$ & $\begin{array}{c}\text { Perimeter: } \\
\text { area ratio }\end{array}$ & $\begin{array}{c}\text { Growth } \\
\text { form }\end{array}$ & $\begin{array}{c}\text { Position } \\
\text { in canopy }\end{array}$ & $\begin{array}{c}\text { Flowering } \\
\text { yes/no }\end{array}$ \\
\hline 2 & Bryan & 8 & 0.09 & 0.29 & Tree/suckers & Understory & No \\
8 & Candler & 33 & 0.11 & 0.17 & Tree & Understory & Yes \\
9 & Candler & 75 & 0.27 & 0.18 & Tree & Understory & Yes \\
11 & Candler & 17 & 0.04 & 0.22 & Tree & Understory & Yes \\
12 & Coffee & 12 & 0.04 & 0.27 & Suckers & Understory & No \\
13 & Coffee & 30 & 0.11 & 0.16 & Tree/suckers & Understory & Yes \\
16 & Evans & 17 & 0.08 & 0.64 & Tree & Understory & Yes \\
17 & Evans & 12 & 0.12 & 0.46 & Tree/suckers & Understory & Yes \\
18 & Evans & $>1000$ & 4.54 & 0.02 & Tree/suckers & Understory & Yes \\
21 & Long & 2 & 0.01 & 0.49 & Suckers & Understory & Yes \\
22 & Long & 23 & 0.08 & 0.17 & Suckers & Understory & Yes \\
23 & Tatnall & $>100$ & 14.59 & 0.01 & Tree & Overstory & Yes \\
24 & Tatnall & $>250$ & 1033.01 & 0.004 & Tree & Under/overstory & Yes \\
25 & Tatnall & 11 & 0.02 & 0.34 & Tree & Understory & Yes \\
26 & Tatnall & 42 & 0.08 & 0.21 & Tree & Under/overstory & Yes \\
28 & Wheeler & 2 & 0.01 & 0.53 & Tree & Overstory & No \\
\hline
\end{tabular}

${ }^{\mathrm{z} E v i d e n c e}$ of flowering included visible floral parts or persistent inflorescence rachis. 
mutations are genetic consequences of small populations (Dudash and Fenster, 2000; Young et al., 1996). Our recent studies on the molecular analysis of georgia plume populations found that small populations containing less than 50 individuals had more genetic similarity than populations with larger numbers of plants (Porter et al., 2012). Further studies are warranted to ascertain if lack of genetic diversity within populations is limiting reproduction.

The geographical area of georgia plume populations is shown in Table 1 and can be characterized as being extremely small in area. Over $80 \%$ of the georgia plume populations (13 of 16) were smaller than 0.3 ha in area; over $56 \%$ of the populations were smaller than 0.1 ha. Three populations (No. 18,23 , and 24) were considerably larger in size, i.e., 4.5, 14.6, and 1033 ha, respectively. The geographic size of a population can play an important role in reproduction. Small, isolated populations have increase extinction risks resulting from a multitude of factors including increased inbreeding, inbreeding depression, lower individual or population fitness, and increased stochasticity (Lienert, 2004). Furthermore, small population size can negatively affect pollinator abundance and can lead to disruption of activity, which subsequently can affect pollination, fertilization, and seed production. Previous observations with georgia plume have noted that fruit and seed set were higher in populations in which higher numbers of individuals exist (Godt and Hamrick, 1999). In studies with Heliconia, Bruna (2002) found that seedling recruitment was several times more likely in large continuous habitats than in smaller fragments.

Growth form characteristics of georgia plume plants summarized in Table 1 show that $\approx 56 \%$ of extant georgia plume sites exclusively contained tree forms of the plant. Although georgia plume is described to form root suckers (Fordham, 1991), this occurred to any degree in less than half of the populations visited, indicating limited vegetative propagation occurs at these locations and that lack of sexual reproduction has important implications. Tree form did not appear to be related to site characteristics except for evidence of burning (Table 2). In all but one population, sites that contained exclusively tree forms were also those that showed no burn evidence. This seems to be consistent with burning in other ecosystems where some species resist fire by resprouting after a fire event (Keeley, 1987). The idea that removal of a natural fire regime has disrupted the natural seed germination ecology in georgia plume has been put forth (Chafin, 2007). Controlled burning as a management tool can have a pronounced effect on tree form and reproduction signifying that the frequency and intensity of controlled burning should be monitored. For example, populations 17,18 , and 22 are on land that is managed for military use and frequently burned. Plants at these locations were characteristically less than $0.5 \mathrm{~m}$ tall and appear to be rootsuckers;

Table 2. Site characteristics of extant georgia plume populations verified by field visits.

\begin{tabular}{|c|c|c|c|c|c|c|c|}
\hline $\begin{array}{l}\text { Population } \\
\text { no. }\end{array}$ & $\begin{array}{l}\text { Data } \\
\text { site }^{z}\end{array}$ & Habitat & $\begin{array}{c}\text { Burn } \\
\text { evidence }^{y}\end{array}$ & $\begin{array}{l}\text { Canopy } \\
\text { type }\end{array}$ & $\begin{array}{l}\text { Canopy } \\
\text { closure }\end{array}$ & Soil cover & $\operatorname{Duff}(\mathrm{cm})$ \\
\hline 2 & $\mathrm{a}$ & Flatwoods & No & Deciduous & Partial & Ground plants & $0-5$ \\
\hline 8 & $\mathrm{a}$ & Sandhill & No & Mixed & Partial & Mixed & $0-5$ \\
\hline 8 & $\mathrm{~b}$ & Sandhill & Yes & Mixed & Open & Mixed & $0-5$ \\
\hline 9 & $\mathrm{a}$ & Flatwoods & No & Mixed & Partial & Ground plants & $0-5$ \\
\hline 11 & $\mathrm{a}$ & Flatwoods & No & Mixed & Partial & Ground plants & $0-5$ \\
\hline 12 & $\mathrm{a}$ & Sandstone outcrop & Yes & Mixed & Open & Ground plants & $0-5$ \\
\hline 13 & $\mathrm{a}$ & Palmetto woods & No & Mixed & Partial & Leaves/needles & $>5$ \\
\hline 16 & $\mathrm{a}$ & Sandhill & No & Mixed & Partial & Ground plants & $0-5$ \\
\hline 16 & $\mathrm{~b}$ & Sandhill & No & Deciduous & Partial & Ground plants & $0-5$ \\
\hline 17 & $\mathrm{a}$ & Sandhill & No & Evergreen & Open & Leaves/needles & $0-5$ \\
\hline 17 & $\mathrm{~b}$ & Sandhill & Yes & Evergreen & Partial & Ground plants & $0-5$ \\
\hline 18 & $\mathrm{a}$ & Sandhill & Yes & Evergreen & Open & Leaves/needles & $0-5$ \\
\hline 18 & $\mathrm{~b}$ & Mixed bottom & Yes & Deciduous & Partial & Leaves/needles & $0-5$ \\
\hline 18 & $\mathrm{c}$ & Flatwoods & Yes & Evergreen & Open & Ground plants & $0-5$ \\
\hline 18 & $\mathrm{~d}$ & Flatwoods & Yes & Evergreen & Open & Ground plants & $0-5$ \\
\hline 21 & $\mathrm{a}$ & Flatwoods & Yes & Evergreen & Open & Ground plants & $0-5$ \\
\hline 22 & $\mathrm{a}$ & Flatwoods & Yes & Evergreen & Open & Ground plants & $0-5$ \\
\hline 23 & $\mathrm{a}$ & Sandhill & No & Deciduous & Partial & Ground plants & $0-5$ \\
\hline 23 & $\mathrm{~b}$ & Oak hammock & No & Mixed & Open & Ground plants & $0-5$ \\
\hline 23 & $\mathrm{c}$ & $\begin{array}{l}\text { Sandhill-river } \\
\text { ecotone }\end{array}$ & No & Mixed & Open & Lichens & $0-5$ \\
\hline 24 & $\mathrm{a}$ & Sandhill & No & Deciduous & Partial & Ground plants & $0-5$ \\
\hline 24 & $\mathrm{~b}$ & Oak hammock & No & Deciduous & Open & Ground plants & $0-5$ \\
\hline 24 & $\mathrm{c}$ & Mesic & No & Mixed & Closed & Ground plants & $0-5$ \\
\hline 25 & $\mathrm{a}$ & $\begin{array}{l}\text { Sandhill-river } \\
\text { ecotone }\end{array}$ & No & Deciduous & Closed & Leaves/needles & $0-5$ \\
\hline 26 & $\mathrm{a}$ & Slope & No & Mixed & Partial & Ground plants & $0-5$ \\
\hline 26 & $\mathrm{~b}$ & Flatwoods & No & Mixed & Open & Leaves/needles & $0-5$ \\
\hline 28 & $\mathrm{a}$ & Sandhill & No & Mixed & Open & Ground plants & $0-5$ \\
\hline
\end{tabular}

${ }^{\mathrm{z}}$ In populations with changing habitats, data were recorded at multiple data collection sites.

${ }^{y}$ Evidence of burning in the last several years as a result of charred tree bark, charred debris, etc.

at these locations, managers have made attempts to reduce the severity of fires around georgia plume plants (H. Mincy, personal communication).

Georgia plume plants predominately had an understory position in the canopy (Table 1 ), which was evident in over $88 \%$ of the active populations. Despite reports of low to nonexistent seed production, $81 \%$ of the active population sites contained at least some plants showing evidence of flowering with abundant production observed on some individuals. In selected populations $(8,9,11$, $12,13)$, trees were individually assessed for reproduction. Evidence of flowering ranged from $39 \%$ to $88 \%$ of individual georgia plume plants within their respective populations. Informal field observations indicated flowers rarely set fruit, i.e., a floral rachis, was evident with few or no attached capsules; if capsules were present, they contain few seed. In recent times, no seedlings have been observed in the wild, indicating an absence of sexual recruitment. A paucity of seed production has been noted by a number of authors (Del Tredici, 1987; Faircloth, 1970; Fordham, 1991; Radcliffe et al., 2010). Our observed evidence of flower production in many populations indicates that lack of flowering per se is not the cause of lack of sexual reproduction in the wild. Our earlier studies on the reproductive biology of georgia plume found that flowering is dichogamous with pollen release occurring before stigma receptivity. This separation in timing of male and female function promotes the need for an outcross source of pollen, which can be problematic if plant numbers within a population are low. In addition, poor pollen quality may be contributing to lack of seed production in some populations; low to moderate pollen viability has been reported (Radcliffe et al., 2010; Santamour, 1967). Further studies are needed to assess flower function, pollination, sexual compatibility, and fruit abortion as potential causes for lack of sexual reproduction in this species.

Field assessments/environmental data. Site characteristics are summarized for the active populations containing georgia plume (Table 2). In some cases, the habitat changed within an individual population, in which case data were recorded in dissimilar habitat areas to capture the changes; within the 16 active populations, 27 habitat recordings were taken. Although active populations were found in variable habitats, sandhill (44\%) and flatwoods (44\%) were major types of habitats found for georgia plume populations (Table 2). Other habitat types and the percentage of active populations containing the respective habitat type are oak hammock $(13 \%)$ and ecotone between sandhill and river $(13 \%)$. Some habitats were represented by a single extant population: mesic, slope, sandstone outcrop, mixed bottom, and palmetto woods. As noted earlier, georgia plume is frequently an understory plant (Table 1). The prevalent type of canopy above georgia plume was a mixed evergreen/deciduous canopy found in $63 \%$ of populations (Table $2)$. Other canopy types found within populations were evergreen $(31 \%)$ and deciduous (38\%). Canopy closure in active georgia 
plume populations was generally open to partially closed with only two populations $(13 \%)$ containing a closed canopy area. Ground plants were the major type of soil cover and present in $81 \%$ of active georgia plume populations. One-third of these populations were observed to have some evidence of recent burning in the form of charred tree bark or litter. Duff thickness at all populations was $5 \mathrm{~cm}$ or less, except at one location.

Field visits confirmed that georgia plume has disappeared from a large number of previously reported locations. Listed in Table 3 are site characteristics of the 12 locations where georgia plume is no longer present. A summary of these inactive sites is presented to provide insight into factors that may have contributed to species loss at these locations. Within these inactive populations, human activity was directly attributable to loss of georgia plume in $58 \%$ of these locations (i.e., seven of 12 sites). Current land use included established pine plantations, agricultural cropland, and, in one case, a gravel pit. Ceballos et al. (2010) noted that agricultural land use has greatly reduced the range of native plant communities. Brockerhoff et al. (2008) examined native forest losses in New Zealand and found that the loss of approximately two-thirds of this cover, as a result of clearing for agricultural use or other forms of development, was a major contributor to loss of biodiversity. Anthrogenic disturbances were the most important influence on local population extinctions of remnant sugar maple (Acer saccharum subsp. skutchii) populations, overriding other variables (VargasRodriguez and Platt, 2012). Considerable habitat loss resulting from agricultural development has contributed to reduced numbers of Dictamnus albus (Hensen and Wesche, 2006); suitable habitat for the species has become rare and surrounded by agricultural fields leading to the loss of between $15 \%$ and $20 \%$ of populations.

Direct causes for the absence of georgia plume plants at five ground-visited sites could not be determined. Conditions at these inactive sites included mesic, sandhill-river ecotone, and bottom land habitats that did not appear to differ appreciably from active sites. Many of the extant georgia plume populations are composed of very few individuals and are within a small geographical area. Mortality of existing plants in conjunction with lack of clonal and sexual reproduction could result in population extinction.

Although landowner permission was obtained to visit $52 \%$ of all known populations, i.e., 32 of 57 sites, this left a number of sites unavailable for field visitation. These remaining sites were evaluated instead using aerial photographs from 2009 in ArcGIS Explorer with assessments listed in Table 4. Of 29 putative populations, $66 \%$ of the locations (19 sites) were judged highly unlikely to contain georgia plume plants based on current land use. These estimates were based on the clear presence of land use conversions to planted pines, clear-cuts, or agricultural fields. In the same way, 10 of 29

Table 3. Site characteristics of locations where georgia plume is no longer present as verified by field visits.

\begin{tabular}{|c|c|c|c|c|c|c|}
\hline $\begin{array}{l}\text { Population } \\
\text { no. }\end{array}$ & $\begin{array}{l}\text { Habitat } \\
\text { type }\end{array}$ & $\begin{array}{c}\text { Canopy } \\
\text { type }\end{array}$ & $\begin{array}{l}\text { Canopy } \\
\text { closure }\end{array}$ & Soil cover & $\begin{array}{c}\text { Burn } \\
\text { evidence }\end{array}$ & $\operatorname{Duff}(\mathrm{cm})$ \\
\hline 1 & Mesic & Deciduous & Partial & Ground plants & No & $0-5$ \\
\hline 3 & Gravel pit & Mixed & Closed & Ground plants & No & $0-5$ \\
\hline 4 & Planted pine & Evergreen & Partial & Leaves/needles & No & $0-5$ \\
\hline 5 & $\begin{array}{l}\text { Sandhill-river } \\
\text { ecotone }\end{array}$ & Mixed & Closed & Leaves/needles & No & $0-5$ \\
\hline 6 & Cleared pine & None & Open & Bare/pine seedlings & Yes & $0-5$ \\
\hline 7 & Planted pine & Evergreen & Partial & Ground plants & No & $0-5$ \\
\hline 10 & Agricultural field & None & Open & Ground plants & No & $0-5$ \\
\hline $11 \mathrm{a}$ & Fern bog & Deciduous & Open & Ground plants & No & $>5$ \\
\hline $11 \mathrm{~b}$ & Bottom land & Mixed & Closed & Leaves/needles & No & $>5$ \\
\hline 14 & Rocky slope & Mixed & Partial & Leaves/needles & No & $0-5$ \\
\hline 15 & Bottom land & Mixed & Closed & Leaves/needles & Yes & $0-5$ \\
\hline $20 \mathrm{a}$ & Sandstone outcrop & None & Open & Bare/lichens & No & $0-5$ \\
\hline $20 \mathrm{~b}$ & Planted pine & Mixed & Partial & Leaves/needles & No & $0-5$ \\
\hline 27 & Planted pine & Evergreen & Partial & Leaves/needles & No & $0-5$ \\
\hline
\end{tabular}

Table 4. Assessments of the occurrence of georgia plume plants at unvisited sites based on surveys of aerial photographs. $^{\text {. }}$

\begin{tabular}{|c|c|c|c|}
\hline \multicolumn{2}{|c|}{ Sites unlikely to contain georgia plume } & \multicolumn{2}{|c|}{ Sites needing further investigation } \\
\hline Population no. & Apparent habitat & Population no. & Apparent habitat \\
\hline 29 & Planted pine & 48 & Hardwood \\
\hline 30 & Planted pine & 49 & Pine/hardwood \\
\hline 31 & Planted pine & 50 & Hardwood \\
\hline 32 & Planted pine & 51 & Hardwood bottom \\
\hline 33 & Planted pine & 52 & Hardwood \\
\hline 34 & Agric. field & 53 & Pine/hardwood \\
\hline 35 & Cleared land & 54 & Hardwood/sandhill \\
\hline 36 & Planted pine & 55 & Pine/hardwood \\
\hline 37 & Agric. field/cleared land & 56 & Hardwood/sandhill \\
\hline 38 & Planted pine & 57 & Pine/hardwood \\
\hline 39 & Planted pine & & \\
\hline 40 & Planted pine & & \\
\hline 41 & Planted pine & & \\
\hline 42 & Planted pine & & \\
\hline 43 & Cleared land & & \\
\hline 44 & Planted pine & & \\
\hline 45 & Planted pine & & \\
\hline 46 & Planted pine & & \\
\hline 47 & Agric. field & & \\
\hline
\end{tabular}

${ }^{\mathrm{z}}$ Sites were previously reported as active georgia plume populations and were designated as unlikely to currently contain georgia plume or needing ground visitation for conformation.

sites were estimated to potentially contain georgia plume plants based on the appearance of an undisturbed canopy cover and were thus designated as sites needing further ground visitation for confirmation (Table 4). Canopy cover was used as the main criterion in determining the possible presence of georgia plume from aerial photographs because it was linked with presence of georgia plume during field surveys and was clearly visible in photographs. Results from aerial photographs are not meant to be used as a substitute for field observations concerning presence of georgia plume but are helpful to prioritize such visits by avoiding locations that are clearly destroyed. Aerial photographs are also a useful tool to use in conjunction with habitat suitability models.

\section{Conclusions}

Accurate mapping, inventory assessment, and habitat descriptions of rare and endangered plant species are of critical importance for the development of conservation strategies. This study shows how GIS/GPS-based methods can be effectively used in data collection, record management, population inventorying, and habitat assessment of georgia plume, a rare endemic plant. These tools can easily be applied to other threatened or endangered plant species.

The current study verifies the extreme rarity of georgia plume. Field ground visits in conjunction with aerial photography assessments indicate that approximately half of previously noted populations no longer exist. The total known distribution of the species is limited to 16 extant populations confirmed by field visits with an additional 10 sites needing further verification. Over $80 \%$ of extant georgia plume populations have an area of less than 0.3 ha. Furthermore, populations are predominantly composed of few individuals with nearly $75 \%$ of populations containing 50 or fewer individuals. The presence of these extremely small populations leaves it vulnerable to local extinction as indicated by the rapid loss of populations observed within the past several decades.

Anthropogenic disturbances such as land use conversion to pine plantations and agricultural cropland were directly attributable to loss of $58 \%$ of putative populations found to 
be inactive after further field visits; $66 \%$ of putative populations evaluated using aerial photography had land use unsuitable for georgia plume. The limited species distribution and rapid loss of population numbers in conjunction with a lack of observed sexual recruitment in the wild indicate that conservation strategies should include protection of extant populations and implementation of ex situ conservation programs incorporating safeguarding, in vitro propagation, and reintroduction.

\section{Literature Cited}

Alexander, M.T., L.M. Worthen, and J.H. Craddock. 2005. Conservation of Castanea dentata germplasm of the southeastern United States. Acta Hort. 693:485-490.

Anderson, R.P. and E. Martinez-Meyer. 2004. Modeling species' geographic distributions for preliminary conservation assessments: An implementation with the spiny pocket mice (Heteromys) of Ecuador. Biol. Conserv. 116:167-179.

Brockerhoff, E.G., W.B. Shaw, B. Hock, M. Kimberley, P. Thomas, J. Quinn, and S. Pawson. 2008. Re-examination of recent loss of indigenous cover in New Zealand and the relative contributions of different land uses. N. Z. J. Ecol. 32:115-126.

Bruna, E.M. 2002. Effects of forest fragmentation on Heliconia acuminata seedling recruitment in central Amazonia. Oecologia 132:235-243.

Ceballos, G., A. Davidson, R. List, J. Pacheco, P. Manzano-Fischer, G. Santos-Barrera, and J. Cruzado. 2010. Rapid decline of a grassland system and its ecological and conservation implications. PLoS One 5:1-12.

Chafin, L.J. 2007. Field guide to the rare plants of Georgia. The State Botanical Garden of Georgia, Athens, GA.

Clark, J.D., J.E. Dunn, and K.G. Smith. 1993. A multivariate model of female black bear habitat use for a geographic information system. J. Wildl. Mgt. 57:519-526.

Coates, D.J., J.F. Sampson, and C.J. Yates. 2007. Plant mating systems and assessing population persistence in fragmented landscapes. Aust. J. Bot. 55:239-249.

Del Tredici, P. 1987. Lost and found: Elliottia racemosa. Arnoldia 47:3-8.

Dudash, M. and C.B. Fenster. 2000. Inbreeding and outbreeding depression in fragmented populations, p. 35-53. In: Young, A.G. and G.M Clarke (eds.). Genetics, demography and viability of fragmented populations. Cambridge Univ. Press, New York, NY.

Duncan, W.H. and M.B. Duncan. 1978. Elliottia in the piedmont of Georgia. Castanea 43:182-184.

Elliott, S. 1821. A sketch of the botany of South Carolina and Georgia. Vol. I. J.R. Schenk, Charleston, SC

Ewan, J. 1968. William Bartram: Botanical and zoological drawings. Memories of the Amer. Philosop. Soc. 74:1-180.

Faircloth, W.R. 1970. An occurrence of Elliottia in central south Georgia. Castanea 35:58-61.

Fordham, A.J. 1991. Elliottia racemosa and its propagation. Arnoldia 51:59-62.

Georgia Department of Natural Resources. 2006. Georgia's state protected animals and plants. Wildlife Resources Division-Nongame Conservation Section, Social Circle, GA.

Godt, M.J.W. and J.L. Hamrick. 1999. Population genetic analysis of Elliottia racemosa (Ericaceae), a rare Georgia shrub. Mol. Ecol. 8:75-82.

Hensen, I. and K. Wesche. 2006. Relationships between population size, genetic diversity and fitness components in the rare plant Dictamnus albus in central Germany. Biodivers. Conserv. 15:2249-2261.

Keeley, J.E. 1987. Role of fire in seed germination of woody taxa in California chaparral. Ecology 68:434-443.

Lienert, J. 2004. Habitat fragmentation effects on fitness of plant populations - A review. J. Nat. Conserv. 12:53-72.
Matthies, D., I. Brauer, W. Maibom, and T. Tscharntke. 2004. Population size and the risk of local extinction: Empirical evidence from rare plants. Oikos 105:481-488.

Miller, H.A. 1978. The story of Elliottia, a primitive, slow-growing member of the heath family that is rare in more ways than one. Amer. Forests 84:24-27.

Patrick, T.S., J.R. Allison, and G.A. Krakow. 1995. Protected plants of Georgia. Georgia Department of Natural Resources, Social Circle, GA.

Porter, J.A., H.Y. Wetzstein, D. Berle, P.A. Wadl, and R.N. Trigiano. 2012. Molecular analysis for conservation of georgia plume, a threatened endemic, using random amplified polymorphic DNA. HortScience 47:563569.

Radcliffe, C.A., J.M. Affolter, and H.Y. Wetzstein. 2010. Floral morphology and development in georgia plume, Elliottia racemosa (Ericaceae), a rare coastal plain endemic. HortScience 135: 487-493.

Rotenberry, J.T., K.L. Preston, and S.T. Knick. 2006. GIS-based niche modeling for mapping species' habitat. Ecology 87:14581464.

Santamour, F.S., Jr. 1967. Cytology and sterility in Elliottia racemosa. Morris Arbor. Bul. 18:60-63.

Vanderpoorten, A., A. Sotiaux, and P. Engels. 2005. A GIS-based survey for the conservation of bryophytes at the landscape scale. Biol. Conserv. 121:189-194.

Vargas-Rodriguez, Y.L. and W.J. Platt. 2012. Remnant sugar maple (Acer saccharum subsp. skutchii) populations at their range edge: Characteristics, environmental constraints and conservation implications in tropical America. Biol. Conserv. 150:111-120.

Young, A., T. Boyle, and T. Brown. 1996. The population genetic consequences of habitat fragmentation for plants. Trends Ecol. Evol 11:413-418. 